\title{
Candida tibetensis sp. nov. and Candida linzhiensis sp. nov., novel anamorphic, ascomycetous yeast species from Tibet
}

\author{
Zuo-Wei Wu ${ }^{1,2}$ and Feng-Yan Bai ${ }^{1}$ \\ ${ }^{1}$ Systematic Mycology and Lichenology Laboratory, Institute of Microbiology, The Chinese \\ Academy of Sciences, Beijing 100080, China \\ ${ }^{2}$ Graduate School of The Chinese Academy of Sciences, Beijing 100039, China
}

Feng-Yan Bai

baify@im.ac.cn

\begin{abstract}
Three anamorphic, ascomycetous yeast strains isolated from plant samples collected in Linzhi District, Tibet, China, were revealed as representing two novel species by 26S rRNA gene D1/D2 domain sequence and physiological property comparisons. The names Candida tibetensis sp. nov. and Candida linzhiensis sp. nov. are proposed for these novel species, with XZ 41-6 ${ }^{\top}$ (=AS $2.3072^{\top}=$ CBS $\left.10298^{\top}\right)$ and $X Z 92-1^{\top}\left(=\right.$ AS $2.3073^{\top}=$ CBS $\left.10299^{\top}\right)$ as the respective type strains. D1/D2 sequence analysis showed that $C$. tibetensis and $C$. linzhiensis are closely related to Candida caryicola and Candida sequanensis, respectively.
\end{abstract}

Candida tanzawaensis and Candida sequanensis were among the species of ascomycetous yeasts that were on isolated branches in the phylogenetic trees drawn from 26S rRNA gene D1/D2 domain sequences (Kurtzman \& Robnett, 1997, 1998). Recently, more than 20 species with close phylogenetic relationships to C. tanzawaensis were described (Kurtzman, 2001; Suh et al., 2004). Most of the species were isolated from sources associated with insects. Consequently, the C. tanzawaensis clade has been expanded substantially. However, no close relatives of $C$. sequanensis have been reported.

In an investigation on Tibetan yeast diversity, two novel anamorphic, ascomycetous yeast species were identified. One of them was closely related to $C$. sequanensis, and the other to Candida caryicola. C. caryicola was described by Kurtzman (2001) as a species weakly associated with the $C$. tanzawaensis clade.

The yeast strains examined were isolated by an enrichment method using YM medium containing penicillin $(100 \mu \mathrm{g}$ $\left.\mathrm{ml}^{-1}\right)$ and tetracycline $\left(25 \mu \mathrm{g} \mathrm{ml}^{-1}\right)$ to inhibit the growth of bacteria. Strains XZ 41-6 ${ }^{\mathrm{T}}, \mathrm{XZ}$ 69C3 and XZ 92-1 ${ }^{\mathrm{T}}$ were isolated from the flowers, leaves and fruit, respectively, of unidentified plants. These samples were collected in July 2004 from Linzhi District, Tibet, at altitudes of 3100-3300 m.

Most of the morphological, physiological and biochemical characteristics were examined according to standard

Published online ahead of print on 31 December 2005 as DOI 10.1099/ijs.0.64174-0.

The GenBank/EMBL/DDBJ accession numbers for the internal transcribed spacer and the 26S rRNA gene D1/D2 domain sequences of strains XZ 41-6 ${ }^{\top}$ and XZ 92-1 ${ }^{\top}$ are DQ269920 and DQ269921, respectively. methods (Yarrow, 1998). Assimilation of nitrogen compounds was investigated on solid media with starved inocula (Nakase \& Suzuki, 1986). Extraction, purification and identification of ubiquinones were carried out according to Yamada \& Kondo (1973).

Nuclear DNA was extracted by the method of Makimura et al. (1994). The DNA fragment covering the internal transcribed spacer region (including $5 \cdot 8 \mathrm{~S}$ rDNA) and the $26 \mathrm{~S}$ rDNA D1/D2 domain was amplified and sequenced by using a method described previously (Lu et al., 2004). Sequences were aligned with the program CLUSTAL X (Thompson et al., 1997). Molecular phylogenetic analysis was performed by using the methods described by Bai et al. (2002). Reference sequences were retrieved from GenBank under the accession numbers indicated in the tree shown in Fig. 1.

Strains XZ 41-6 ${ }^{\mathrm{T}}$ and XZ 69C3 have identical D1/D2 and internal transcribed spacer sequences. In the phylogenetic tree drawn from the D1/D2 sequence alignment (Fig. 1), the two strains clustered together with C. caryicola. They differed from $C$. caryicola by $5 \cdot 2 \%$ mismatches ( 25 substitutions and 4 indels) in the D1/D2 domain. Strain XZ 92-1 ${ }^{\mathrm{T}}$ was closely related to $C$. sequanensis (Fig. 1). This strain differed from C. sequanensis by $1 \cdot 8 \%$ (10 substitutions) nucleotide divergence in the D1/D2 domain. Another close relative of strain XZ 92- ${ }^{\mathrm{T}}$ shown in the tree was Candida melibiosacea, which was recently reinstated as a distinct species by Daniel (2003), with Trichosporon melibiosaceum - a former synonym of Candida fennica (Meyer et al., 1984) - as the basionym.

The novel Candida species described by Kurtzman (2001) and Suh et al. (2004), with the exception of C. caryicola, formed a strongly supported clade with $C$. tanzawaensis. C. caryicola was described as a species basal to the $C$. 


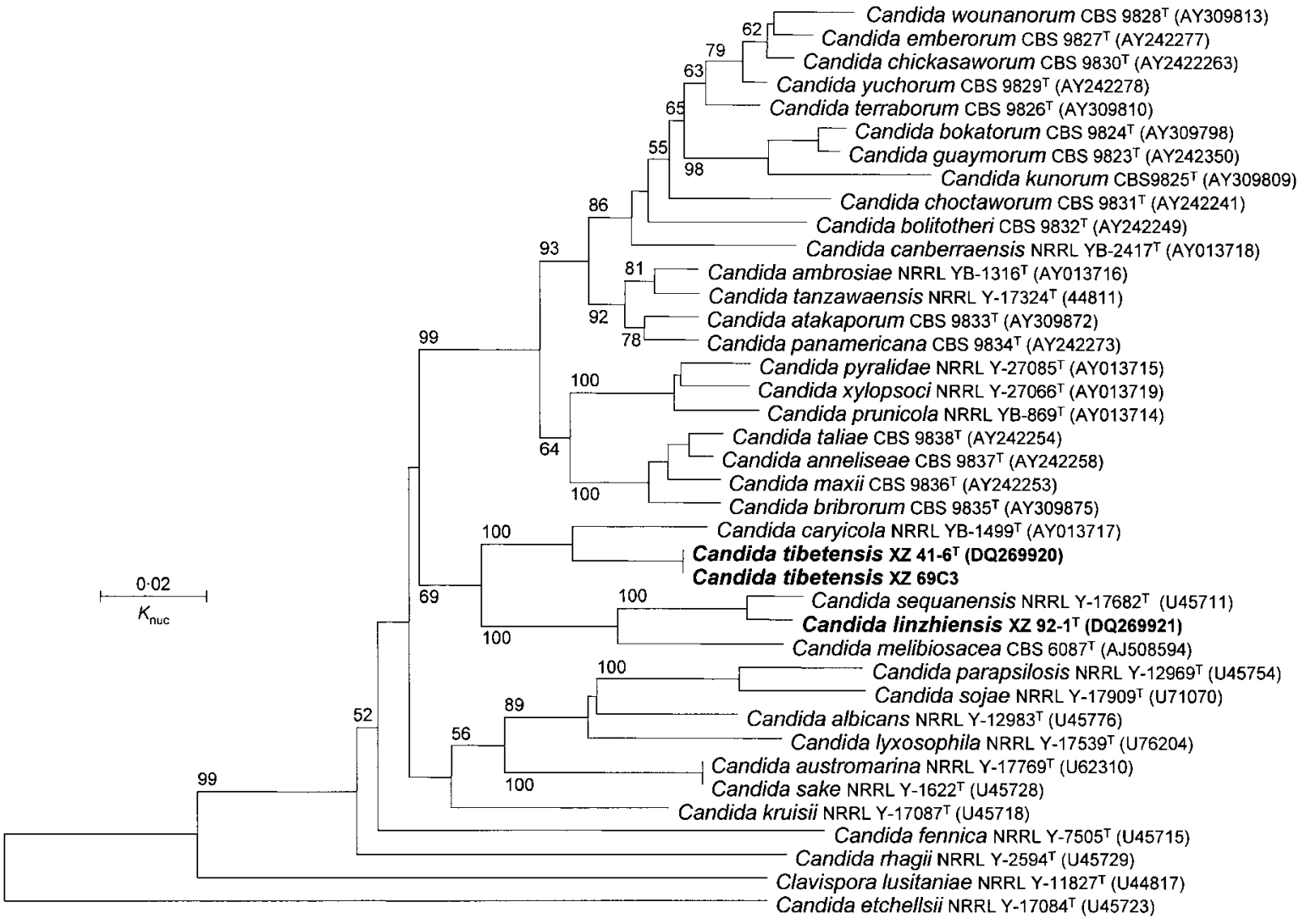

Fig. 1. Phylogenetic tree drawn from neighbour-joining analysis of $26 \mathrm{~S}$ rRNA gene D1/D2 domain sequences, depicting the relationship of the two novel Candida species with respect to closely related taxa. Bootstrap percentages above $50 \%$ (from 1000 bootstrap replicates) are shown. Reference sequences were retrieved from GenBank under the accession numbers indicated. Bar, $0.02 K_{\text {nuc }}$ units.

tanzawaensis clade and weakly associated with the clade (Kurtzman, 2001). However, with the addition of novel species to the existing clades, the present study shows that C. caryicola appears to be more closely related to the clade represented by $C$. sequanensis than to the $C$. tanzawaensis clade (Fig. 1).

In agreement with their identical D1/D2 and internal transcribed spacer sequences, strains XZ 41-6 ${ }^{\mathrm{T}}$ and XZ 69C3 were similar in terms of morphological and physiological characteristics, indicating that they are conspecific. They differed from the phylogenetically closest relative, C. caryicola, in the assimilation reactions with cellobiose, D-xylose, $\mathrm{L}$-arabinose, D-arabinose and D-ribose, and in terms of growth in vitamin-free medium. Strain XZ $92-1^{\mathrm{T}}$ differed from its closest relative, C. sequanensis, in the assimilation reactions with L-sorbose, lactose, melibiose, raffinose, soluble starch, D-ribose, erythritol, methyl $\alpha$-D-glucoside, hexadecane and L-lysine and in terms of growth in vitaminfree medium.

The molecular and physiological comparison demonstrated that strains XZ 41-6 ${ }^{\mathrm{T}}$ and XZ $92-1^{\mathrm{T}}$ represent two distinct novel ascomycetous yeast species. As sexual states were not observed in cultures of single strains or in mating tests (between strains XZ 41-6 ${ }^{\mathrm{T}}$ and XZ 69C3) on various media, including potato dextrose agar, $5 \%$ malt extract agar, yeast carbon base (YCB) agar, cornmeal agar, acetate agar and dilute V8 agar (Yarrow, 1998), they were assigned to the genus Candida Berkhout according to the current taxonomy of yeasts (Kurtzman, 1998; Meyer et al., 1998). Therefore, we propose the names Candida tibetensis sp. nov. and Candida linzhiensis sp. nov. for strains XZ $41-6^{\mathrm{T}}$ and XZ 92-1 ${ }^{\mathrm{T}}$, respectively.

\section{Latin diagnosis of Candida tibetensis Bai \& Wu sp. nov.}

In medio liquido $\mathrm{YM}$ post dies 3 ad $25^{\circ} \mathrm{C}$, cellulae cylindratae ad bacillaris, $2 \cdot 5-2 \cdot 7 \times 5 \cdot 0-21 \cdot 4 \mu \mathrm{m}$, singulae, binae, catenulatae vel paniculatae. Per gemmationem multipolarem reproducentes. Post 1 mensem sedimentum et annulus formantur. In agaro YM post 1 mensem ad $25^{\circ} \mathrm{C}$, butyrosa, membrancea, cremea, sordida, glabra, rugosa cum vittatum tuberculum, margo undulata. In agaro farinae Zea mays post dies 7, pseudohyphae fiunt. Ascosporae non fiunt. 
Glucosum fermentatur at non galactosum, sucrosum, maltosum, lactosum nec raffinosum. Glucosum, galactosum, sucrosum, maltosum, cellobiosum (lente), trehalosum, melezitosum, D-xylosum, L-arabinosum, D-arabinosum (lente), D-ribosum (lente; infirme), D-glucosaminum, ethanolum, glycerolum, ribitolum, D-mannitolum, D-glucitolum, methyl $\alpha$-D-glucosidum, salicinum (infirme), acidum succinicum (lente), acidum citricum (infirme), et hexadecanum assimilantur at non L-sorbosum, lactosum, melibiosum, raffinosum, inulinum, amylum solubile, L-rhamnosum, methanolum, erythritolum, galactitolum, acidum DL-lacticum nec inositolum. Ammonium sulfatum, ethylaminum, L-lysinum et cadaverinum assimilantur at non natrum nitrosum nec kalium nitricum. Ad crescentiam vitaminae externae non necessariae sunt. Maxima temperatura crescentiae: $28^{\circ} \mathrm{C}$. Materia amyloidea iodophila non formatur. Diazonium caeruleum B non respondens. Ureum non hydrolysatur. Systema coenzymatis Q-9 adest. Typus depositus in collectione China General Microbiological Culture Collection Center, Academia Sinica (AS 2.3072 ${ }^{\mathrm{T}}$ ).

\section{Description of Candida tibetensis Bai \& Wu sp. nov.}

Candida tibetensis (ti.be.ten'sis. N.L. fem. adj. tibetensis pertaining to Tibet, the geographical origin of the type strain of the species).

In YM broth, after 3 days at $25^{\circ} \mathrm{C}$, the cells are cylindrical to bacilliform, $2.5-2.7 \times 5 \cdot 0-21.4 \mu \mathrm{m}$ and occur singly, in pairs, in chains or in branches (Fig. 2a). Budding is multilateral. After 1 month at $25^{\circ} \mathrm{C}$, sediment and a climbing ring are present. On YM agar, after 1 month at $25^{\circ} \mathrm{C}$, streak culture is butyrous, membranous, cream-coloured, raised, dull, smooth and creased with ridged protuberances; the margin is undulating. In Dalmau plate culture on cornmeal agar, pseudohyphae are formed. Sporulation is not observed. Glucose is fermented, but galactose, sucrose, maltose, lactose and raffinose are not fermented. Glucose, galactose, sucrose, maltose, cellobiose (delayed), trehalose, melezitose, D-xylose, L-arabinose, D-arabinose (delayed), D-ribose (delayed; weak), D-glucosamine, ethanol, glycerol, ribitol, D-mannitol, D-glucitol, methyl $\alpha$-D-glucoside, salicin (weak), succinic acid (delayed), citric acid (weak) and hexadecane are assimilated; L-sorbose, lactose, melibiose, raffinose, inulin, soluble starch, L-rhamnose, methanol, erythritol, galactitol, DL-lactic acid and inositol are not assimilated. Ammonium sulfate, ethylamine hydrochloride, L-lysine and cadaverine dihydrochloride are assimilated; sodium nitrite and potassium nitrate are not assimilated. Grows in vitamin-free medium. Maximum growth temperature is $28^{\circ} \mathrm{C}$. Starch-like compounds are not produced. Diazonium blue B reaction is negative. Negative for urease activity. The major ubiquinone type is Q-9.

The type strain, XZ 41-6 $6^{\mathrm{T}}\left(=\right.$ AS $\left.2.3072^{\mathrm{T}}=\mathrm{CBS} 10298^{\mathrm{T}}\right)$, was isolated from a flower of an unidentified plant collected in Linzhi District, Tibet, in July 2004.

\section{Latin diagnosis of Candida linzhiensis Bai \& Wu sp. nov.}

In medio liquido $\mathrm{YM}$ post dies 3 ad $25^{\circ} \mathrm{C}$, cellulae subglobosae $(2 \cdot 7-5 \cdot 2 \times 3 \cdot 7-6 \cdot 0 \mu \mathrm{m})$, ovoideae ad elongatae $(3 \cdot 7-4 \cdot 5 \times$ $23 \cdot 6-24 \cdot 8 \mu \mathrm{m})$, singulae, binae vel adhaerentes, blastospora fiunt. Per gemmationem multipolarem reproducentes. Post 1 mensem sedimentum et annulus formantur. In agaro $\mathrm{YM}$ post 1 mensem ad $25^{\circ} \mathrm{C}$, butyrosa, viscidulus, cremea, seminitida, glabra cum radiatis et vittatus tuberculum, margo undulata. In agaro farinae Zea mays post dies 7, pseudohyphae et mycelium verum fiunt. Ascosporae non fiunt. Glucosum et galactosum (lente; infirme) fermentantur at non sucrosum, maltosum, lactosum nec raffinosum. Glucosum, galactosum, L-sorbosum (lente), maltosum, cellobiosum, trehalosum, lactosum (lente), melibiosum (lente; infirme), raffinosum (lente; infirme), D-xylosum, L-arabinosum, D-ribosum (lente),
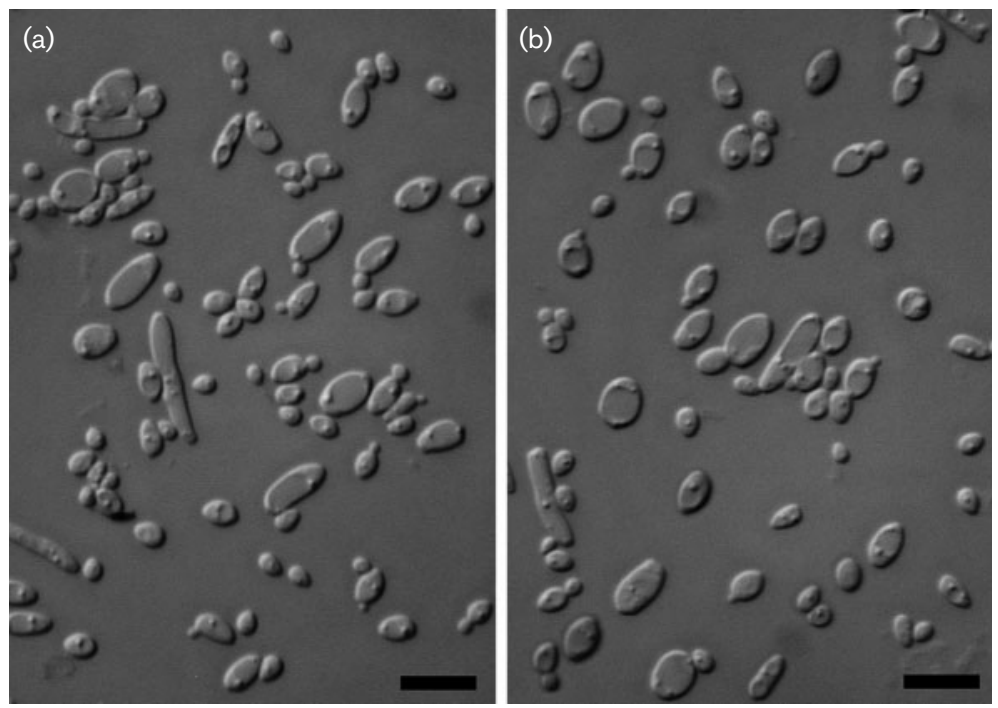

Fig. 2. Vegetative cells of $C$. tibetensis $X Z$ $41-6^{\top}$ (a) and C. linzhiensis $X Z \quad 92-1^{\top}$ (b) grown in $\mathrm{YM}$ broth for 3 days at $25^{\circ} \mathrm{C}$. Bars, $10 \mu \mathrm{m}$. 
ethanolum, glycerolum, erythritolum (lente), ribitolum, D-mannitolum, D-glucitolum, methyl $\alpha$-D-glucosidum, salicinum (lente) et acidum succinicum (lente) assimilantur at non sucrosum, melezitosum, inulinum, amylum solubile, D-arabinosum, L-rhamnosum, D-glucosaminum, methanolum, galactitolum, acidum DL-lacticum, acidum citricum, inositolum nec hexadecanum. Ammonium sulfatum, ethylaminum, et cadaverinum assimilantur at non natrum nitrosum, kalium nitricum nec L-lysinum. Ad crescentiam vitaminae externae non necessariae sunt. Maxima temperatura crescentiae: $28^{\circ} \mathrm{C}$. Materia amyloidea iodophila non formatur. Diazonium caeruleum B non respondens. Ureum non hydrolysatur. Systema coenzymatis Q-8 adest. Typus depositus in collectione China General Microbiological Culture Collection Center, Academia Sinica (AS 2.3073 ${ }^{\mathrm{T}}$ ).

\section{Description of Candida linzhiensis Bai \& Wu sp. nov.}

Candida linzhiensis (lin.zhi.en'sis. N.L. fem. adj. linzhiensis pertaining to Linzhi, the geographical origin of the type strain of the species).

In YM broth, after 3 days at $25^{\circ} \mathrm{C}$, the cells are subglobose $(2 \cdot 7-5 \cdot 2 \times 3 \cdot 7-6 \cdot 0 \mu \mathrm{m})$ to ovoidal to elongate $(3 \cdot 7-4 \cdot 5 \times$ $23 \cdot 6-24 \cdot 8 \mu \mathrm{m})$ and occur singly, in pairs or in groups (Fig. 2b). Elongated cells are straight or curved and may produce small denticles that bear blastoconidia. Budding is multilateral. After 1 month at $25^{\circ} \mathrm{C}$, sediment and a climbing ring are present. On YM agar after 1 month at $25^{\circ} \mathrm{C}$, streak culture is butyrous, viscous, cream-coloured, low and raised, semi-glossy and smooth with faint striations as well as ridged protuberances; the margin is slightly undulating. In Dalmau plate culture on cornmeal agar, pseudohyphae and true hyphae are formed. Sporulation not observed. Glucose and galactose (delayed; weak) are fermented; sucrose, maltose, lactose and raffinose are not fermented. Glucose, galactose, L-sorbose (delayed), maltose, cellobiose, trehalose, lactose (delayed), melibiose (delayed; weak), raffinose (delayed; weak), D-xylose, L-arabinose, D-ribose (delayed), ethanol, glycerol, erythritol (delayed), ribitol, D-mannitol, D-glucitol, methyl $\alpha$-D-glucoside, salicin (delayed) and succinic acid (delayed) are assimilated; sucrose, melezitose, inulin, soluble starch, D-arabinose, L-rhamnose, D-glucosamine, methanol, galactitol, DL-lactic acid, citric acid, inositol and hexadecane are not assimilated. Ammonium sulfate, ethylamine hydrochloride and cadaverine dihydrochloride are assimilated; sodium nitrite, potassium nitrate and L-lysine are not assimilated. Grows in vitamin-free medium, but growth is weak and delayed. Maximum growth temperature is $28^{\circ} \mathrm{C}$. Starch-like compounds are not produced. Diazonium blue B reaction is negative. Negative for urease activity. Major ubiquinone type is Q-8.

The type strain, XZ 92-1 ${ }^{\mathrm{T}}\left(=\mathrm{AS} 2.3073^{\mathrm{T}}=\mathrm{CBS} 10299^{\mathrm{T}}\right)$, was isolated from a fruit of an unidentified plant collected in Linzhi District, Tibet, in July 2004.

\section{Acknowledgements}

We thank Dr H.-M. Daniel, BCCM/MUCL, Belgium, for sending us the PDF file of her thesis relating to the proposal of a novel combination. This study was supported by grant no. 30470005 from the National Natural Science Foundation of China (NSFC).

\section{References}

Bai, F.-Y., Zhao, J.-H., Takashima, M., Jia, J.-H., Boekhout, T. \& Nakase, T. (2002). Reclassification of the Sporobolomyces roseus and Sporidiobolus pararoseus complexes, with the description of Sporobolomyces phaffii sp. nov. Int J Syst Evol Microbiol 52, 2309-2314.

Daniel, H.-M. (2003). Molecular phylogeny applied to Candida species and related ascomycetous yeasts. $\mathrm{PhD}$ thesis, Technical University Berlin, Germany. Berlin: Verlag für Wissenschaft und Forschung.

Kurtzman, C. P. (1998). Discussion of teleomorphic and anamorphic ascomycetous yeasts and a key to genera. In The Yeasts, a Taxonomic Study, 4th edn, pp. 111-121. Edited by C. P. Kurtzman \& J. W. Fell. Amsterdam: Elsevier.

Kurtzman, C. P. (2001). Six new anamorphic ascomycetous yeasts near Candida tanzawaensis. FEMS Yeast Res 1, 177-185.

Kurtzman, C. P. \& Robnett, C. J. (1997). Identification of clinically important ascomycetous yeasts based on nucleotide divergence in $5^{\prime}$ end of the large-subunit (26S) ribosomal DNA gene. J Clin Microbiol 35, 1216-1223.

Kurtzman, C. P. \& Robnett, C. J. (1998). Identification and phylogeny of ascomycetous yeasts from analysis of nuclear large subunit (26S) ribosomal DNA partial sequences. Antonie van Leeuwenhoek 73, 331-371.

Lu, H.-Z., Cai, Y., Wu, Z.-W., Jia, J.-H. \& Bai, F.-Y. (2004). Kazachstania aerobia sp. nov., a novel ascomycetous yeast species from aerobically deteriorating corn silage. Int J Syst Evol Microbiol 54, 2431-2435.

Makimura, K., Murayama, Y. S. \& Yamaguchi, H. (1994). Detection of a wide range of medically important fungi by the polymerase chain reaction. J Med Microbiol 40, 358-364.

Meyer, S. A., Ahearn, D. G. \& Yarrow, D. (1984). Candida Berkhout. In The Yeasts, a Taxonomic Study, 3rd edn, pp. 585-844. Edited by N. J. W. Kreger-van Rij. Amsterdam: Elsevier.

Meyer, S. A., Payne, R. W. \& Yarrow, D. (1998). Candida Berkhout. In The Yeasts, a Taxonomic Study, 4th edn, pp. 454-573. Edited by C. P. Kurtzman \& J. W. Fell. Amsterdam: Elsevier.

Nakase, T. \& Suzuki, M. (1986). Bullera megalospora, a new species of yeast forming large ballistospores isolated from dead leaves of Oryza sativa, Miscanthus sinensis, and Sasa sp. in Japan. J Gen Appl Microbiol 32, 225-240.

Suh, S.-O., McHugh, J. V. \& Blackwell, M. (2004). Expansion of the Candida tanzawaensis yeast clade: 16 novel Candida species from basidiocarp-feeding beetles. Int J Syst Evol Microbiol 54, 2409-2429.

Thompson, J. D., Gibson, T. J., Plewniak, F., Jeanmougin, F. \& Higgins, D. G. (1997). The CLUSTAL_X windows interface: flexible strategies for multiple sequence alignment aided by quality analysis tools. Nucleic Acids Res 25, 4876-4882.

Yamada, Y. \& Kondo, K. (1973). Coenzyme Q system in the classification of the yeast genera Rhodotorula and Cryptococcus and the yeast like genera Sporobolomyces and Rhodosporidium. J Gen Appl Microbiol 19, 59-77.

Yarrow, D. (1998). Methods for the isolation, maintenance and identification of yeasts. In The Yeasts, a Taxonomic Study, 4th edn, pp. 77-100. Edited by C. P. Kurtzman \& J. W. Fell. Amsterdam: Elsevier. 